\title{
Accounting Systems for Records Keeping Practices for Small Enterprise Development in Makueni County, Kenya
}

\author{
Nicodemus Muteti1 ${ }^{*}$, Mary Namusonge ${ }^{1}$, David Nzomo ${ }^{2}$ \\ ${ }^{1}$ Department of Business Administration, School of Business, Kenyatta University, Nairobi, Kenya \\ ${ }^{2}$ Department of Accounting and Finance, School of Business, University of Nairobi, Nairobi, Kenya \\ Email: ^nmmuteti@yahoo.com
}

How to cite this paper: Muteti, N., Namusonge, M. and Nzomo, D. (2018) Accounting Systems for Records Keeping Practices for Small Enterprise Development in Makueni County, Kenya. Open Journal of Accounting, 7, 181-190.

https://doi.org/10.4236/ojacct.2018.73012

Received: June 8, 2018

Accepted: July 28, 2018

Published: July 31, 2018

Copyright $\odot 2018$ by authors and Scientific Research Publishing Inc. This work is licensed under the Creative Commons Attribution International License (CC BY 4.0).

http://creativecommons.org/licenses/by/4.0/

\begin{abstract}
Small enterprise development strategy is used by governments worldwide for economic development, wealth creation and poverty reduction. The government of Kenya vision 2030 of being a medium income economy is anchored on an ambitious economic development blueprint through economic, social and political pillars. While small enterprises are taunted as part of the catalysts for rapid development, by their nature small enterprises face a myriad of challenges in the collection of financial information through accounting system which is used in business decision making. The study considered the challenges faced by the enterprises in record keeping, the type of accounting systems they use and the role of accounting systems in enterprise development in Makueni County, Kenya. Data for the study was collected from 250 small enterprises through semi-structured questionnaires and analysed using descriptive and inferential statistics. Small enterprises prefer maintaining manual records of accounting systems for recording purchases, sales and expenses. The challenges small enterprises faced were lack of competent clerical staff, time constraints and lack of knowledge on record keeping. A significant linear relationship is evident between accounting systems and enterprise development in Makueni County of Kenya. There is need for the government and other stake holders to intervene in capacity building of small enterprises on accounting practices as a pillar to the development and sustainability of small enterprises in Kenya.
\end{abstract}

\section{Keywords}

Accounting Systems, Enterprise Development, Small Enterprises, Records Keeping, Challenges 


\section{Introduction}

Enterprise developments are critical for economic development globally as they catalyze a range of multiplier effects on the economic activities of countries [1]. Primarily small enterprises are accepted worldwide as strategies for accelerating economic development, poverty reduction and creating employment [2]. Small enterprise development contributes slightly over 55 percent of the national gross domestic product (GDP) and over 65 percent of total employment among the high income countries [1]. Enterprises thrive in economies where the government policy-makers put in place policies that support business growth. The developed world continues to offer the African continent the lessons on prudent management of small enterprises to foster wealth and employment creation. The policy documents and economic strategies by most African government ministries and departments mandated to oversee enterprise development continue to emphasize on enterprise development [3].

In developing countries, most of the enterprise development initiatives are aimed at realizing development through enterprise programmes that enhance demand and supply of goods and services in an economy [4]. In the African Continent, small enterprise development contributes to national economic planning and development. Most of the African states notably Senegal and South Africa have taken measures to facilitate the creation of innovative and vibrant enterprises. In Kenya, small enterprises have a major role in poverty reduction, economic development and have acted as pillars of a vibrant private sector [5]. The International Labour Organization (ILO) observes that women make up to 40 percent of owner-managers and nearly half of all small enterprise owners [6]. The small enterprises sector creates employment to an estimated 80 percent of the workforce population and 18 percent of the gross domestic product [7]. Kenya's government vision 2030 is anchored on an ambitious economic development through economic, social and political pillars. The economic pillar objective is to generate more resources to reinvigorate the economy through an average GDP growth rate of 10 percent per annum. Small enterprises are taunted to influence this growth and several initiatives have been put in place such as Youth Fund and Women Enterprise Development Fund [8].

Small enterprises need quality information to make investment decisions, evaluate performance and for planning purposes. Accounting practices improve effectiveness of the enterprise operations and owner managers need to adopt use of accounting systems; which include systems primarily concerned with recording financial events to provide a basis for preparing financial reports. Information collection and maintenance with appropriate accounting systems for small enterprises means there is available information summarized as demanded by stakeholders and external users for business decision making process [9].

\section{Small Enterprises Development}

There is no single and uniformly agreed definition of small enterprises as it va- 
ries from country to country [10] [11] [12]. Small enterprises continue to influence the economic development and employment creation in Sub-Saharan Africa (SSA) [13]. Some of the challenges faced by small enterprises in SSA are lack of clear government policies, scanty data on their contribution to the GDP and absence of accounting systems for records maintenance [10]. The contributions of the small enterprises to world economies cannot be understated. In Korea, they contributed 50.0 percent of the country's GDP, 55.3 percent in Germany, 57.0 percent in China and 47.0 percent in Malaysia in the year 2007 [14].

According to [15], small enterprises support functional and competitive markets as agents of income distribution, industrial expansion and poverty reduction. The owner manager's failure to plan, manage and control the business activities has contributed to the low sustainability of these enterprises [16] [17]. Their performance is depressed by violation of good and sound accounting practices. Accounting professionals should be more involved in small enterprises to assist in prudent accounting processes [2]. A study by [15] found that small enterprises development increased wealth generation, jobs creation and improved economic and social conditions of a nation. Formal and informal small enterprises contributed more than 18.4 percent of Kenya's GDP with most comprising of retail, mining and quarry, agriculture, manufacturing, service/finance and other sub-sectors of the economy [18]. Small enterprises that thrive past their start-up phase and expand are faced with challenges of financial management, securing cash flows and ability to generate information for planning purposes [19]. Skills gap, access to finance and lack of infrastructure tend to compound the challenges. A similar observation by [20] is that enterprise development obstacles include government policies, poor accounting systems, and informal accounting procedures.

\section{Accounting Systems}

A study by [21] on factors that affect adoption of accounting systems in Mauritius adopted a survey method on financial practices of small enterprises in manufacturing. The study found that enterprises that applied accounting practices kept minimum records and produced formal accounts. Financial management systems were used by enterprises in Malaysia even though most owner-managers did not have the requisite qualities of accounting [22]. The importance of management accounting information in Australia is that management accounting is multidisciplinary in nature [23]. Management of accounting research in small enterprises continues to be neglected [24]. A suggestion by [25] is that small enterprises should adopt and apply accounting systems to meet their information and reporting needs. Enterprises face challenges in utilizing accounting systems as it is perceived to be time consuming, difficult to maintain, requires technical knowledge and exposes the enterprise to the taxman. Challenges are not limited to cash flows, application of the right set of skills, use of an effective accounting system and lack of information on the true health of the business. 
Small enterprises daily operations face obstacles that impede their development to sustainable levels. The small enterprises in Ghana faced obstacles in their daily operations from availability of the necessary business skills, cash flows, lack of technology and poor record keeping [13]. There is a lack of guidance on the criterion on selection of accounting systems applicable in small enterprises. Though accounting systems are old in history, their influence on enterprise development in Makueni County, Kenya appears to be minimal or none documented. This information gap led to this study based on selected small enterprises to explore the contribution of accounting systems on enterprise development and the manager's perceptions of accounting systems. The study considered the type of records kept; challenges faced in record keeping and tested the hypothesis that there is no significant influence of accounting systems on small enterprise development in selected small enterprises in Makueni County in Kenya.

\section{Methodology}

The descriptive and cross-sectional research designs were used to capture the situation among the entrepreneurs accounting systems. Sampling is stratified and systematic selected based on the sector of the economy they operate in. The study considered 2000 small enterprises that were registered by Micro and Small Enterprises Authority chapter of Makueni County and operated in the County. The stratification was based on the economic activity of the enterprises; manufacturing, servicing/financial, merchandising and retail, mining and quarrying, agriculture and others. The study concentrated on the key trade corridors in the county where 250 of the enterprises were sampled. The primary data was collected using semi-structured questionnaires. The questionnaire had three sections on; profile of the respondent, the profile of the enterprise and a section on accounting systems and enterprise development. The questionnaires were administered to the owner managers by the researcher to collect both quantitative and qualitative data. Quantitative data had a five likert scale of 1 to 5; where $1=$ not at all, $2=$ slight extent, $3=$ moderate extent, $4=$ great extent, and $5=$ very great extent. Pilot testing was carried out to improve on the data collection instrument. The questionnaires response rate of 91.2 percent was found to be adequate for data analysis. Statistical analysis was based on SPSS version 22 .

\section{Results and Discussions}

This section presents the results and discussions:

In Table 1, most of the owner managers kept manual records (mean $=3.76$, $\mathrm{SD}=1.3$ ), usage of accounting systems to record sales (mean $=3.24, \mathrm{SD}=$ $1.186)$, for recording purchases daily (mean $=3.42, \mathrm{SD}=1.179$ ) and use of systems for recording expenses and payments (mean $=3.09, \mathrm{SD}=1.18$ ). Low to medium variations in the responses had the coefficients of variation ranging 
Table 1. Descriptive statistics on accounting systems.

\begin{tabular}{lccc}
\hline \multicolumn{1}{c}{ Statement } & Mean & $\begin{array}{c}\text { Std. } \\
\text { Deviation }\end{array}$ & $\begin{array}{c}\text { Coefficient of } \\
\text { Variation (percent) }\end{array}$ \\
\hline System for recording sales & 3.19 & 1.186 & 37.179 \\
System for recording purchases daily & 3.42 & 1.179 & 34.474 \\
System for recording expenses and payments & 3.09 & 1.18 & 38.188 \\
Maintains records for costing its goods and services & 2.95 & 1.094 & 37.085 \\
Accounting system generates information & 2.85 & 1.014 & 35.579 \\
Recognizes accounting function & 2.88 & 0.981 & 34.063 \\
Measures to manage costs effectively & 2.83 & 0.897 & 31.696 \\
Use of information for decision making & 2.83 & 0.926 & 32.721 \\
Records generated through computer system & 1.51 & 1.126 & 74.570 \\
Records kept are manual & 3.76 & 1.300 & 34.574 \\
No need to maintain records & 1.73 & 0.89 & 51.445 \\
Proper maintenance of records is costly & 2.12 & 0.848 & 40.000 \\
Owner records off memory & 2.07 & 0.882 & 42.609 \\
Uses accounting systems commonly used & 2.45 & 0.935 & 38.163 \\
Enterprise too small to maintain records & 1.75 & 0.833 & 47.600 \\
In built systems of checks and balances & 2.83 & 0.901 & 31.837 \\
Maintains s system for accounting for its taxes & 2.39 & 0.950 & 39.749 \\
Observes KRA requirements & 2.45 & 1.091 & 44.531 \\
Enterprise has a record for all enterprise assets & 2.15 & 1.406 & 65.395 \\
Aggregate Scores & 2.592 & 1.080 & 41.656 \\
\hline & & & \\
\hline
\end{tabular}

between 31.7 percent and 65.4 percent. The entrepreneurs disagree that there is no need to keep records indicating they valued record keeping. No enterprise felt was too small not to warrant record keeping. Most of the records kept by enterprises in Makueni County were manual which explains the high response on this issue of accounting systems. Low awareness on importance of financial management in enterprises hinders the penetration of the use of accounting systems.

Table 2 highlights the main types of records kept by enterprises where purchases records (28.2 percent), sales (28.0 percent) and expenses (23.0 percent), an indication that enterprises do not value the importance of record keeping.

In Table 3, enterprises faced challenges of records keeping where 20.4 percent cited lack of competent clerical staff, 18.3 percent lack of knowledge on record keeping and 17.8 percent had time constraints. This shows that small businesses are faced with problems in utilizing accounting systems [19].

Table 4 summarizes the reasons for keeping records by the enterprises. Where 26.6 percent kept records for remembering the nature of financial transaction, 25.8 percent kept records for keeping track of enterprises profits, 25.8 percent 
Table 2. Type of records kept.

\begin{tabular}{ccc}
\hline Type of record kept & Frequency & Percent \\
\hline Purchases & 86 & 28.2 \\
Sales & 85 & 28.0 \\
Expenses & 70 & 23.0 \\
Assets & 37 & 12.2 \\
Liabilities & 20 & 6.6 \\
None & 6 & 2.0 \\
Total & 304 & 100
\end{tabular}

Table 3. Major challenges in keeping records.

\begin{tabular}{ccc}
\hline Challenges in record keeping & Frequency & Percent \\
\hline Competence of clerical staff & 41 & 20.4 \\
Knowledge & 37 & 18.3 \\
Time & 36 & 17.8 \\
Manual records & 20 & 9.9 \\
Tedious & 14 & 6.9 \\
Do not know & 14 & 6.9 \\
Lack of finance & 14 & 6.9 \\
Lack of facilities & 11 & 5.4 \\
Identify areas of improvement & 5 & 2.5 \\
None response to proposal & 4 & 2 \\
Continuity & 4 & 2 \\
Fraud & 2 & 1 \\
Total & 202 & 100 \\
\hline
\end{tabular}

Table 4. Reasons for keeping records.

\begin{tabular}{ccc}
\hline Reasons for keeping records & Frequency & Percent \\
\hline Remember & 38 & 26.6 \\
Profit & 37 & 25.8 \\
Progress & 35 & 24.5 \\
Reference & 21 & 14.7 \\
Taxes and compliance & 12 & 8.4 \\
Total & 143 & 100 \\
\hline
\end{tabular}

for profit analysis purposes, 24.5 percent kept records to allow monitoring performance or progress of their enterprises and 14.7 percent kept records as a reference point in the growth of the enterprise. Tax and compliance were not deemed as a good reason for keeping records. Small enterprises avoided keeping 
records as a way of not exposing their actual financial position to the taxman and competitors.

Table 5 highlights the challenges enterprises face in assessing their growth. The main challenges being lack of market for their goods and services (14.41 percent), lack of government intervention (13.56 percent), problem of costing their products and services (11.86 percent) and lack of finance (11.02 percent). Only 0.42 percent of the entrepreneurs did not face any challenges. Most of small enterprises lack the skills, proficiency, competencies and capacity to prepare accounts for their enterprises. Governments, accounting bodies and other stakeholders can offer financial skills to the entrepreneurs to cover this gap in their day-to-day operations through well developed and coordinated accounting systems for sustainability.

The regression analysis in Table 6 indicates a high linear relationship between accounting systems and enterprise development $(\mathrm{R}=0.9, p<0.001)$. In the absence of accounting systems, enterprises would develop with 3.685 units $(p<$ $0.001)$. Accounting systems explains 51.8 percent of the enterprise development with $\mathrm{F}(1,223)=56.011(p<0.001)$. Accounting systems are crucial in enterprise development.

\section{Conclusions}

The study had a limitation due to technical language barrier between the researcher and the respondents. Inability to fully comprehend the questionnaire, education level, and the amount of information that the respondents were

Table 5. Challenges faced by enterprises in assessing their success.

\begin{tabular}{ccc}
\hline Challenges faced by enterprises & Frequency & Percent \\
\hline Lack of market/location & 34 & 14.41 \\
Lack of government intervention & 32 & 13.56 \\
Costing of products/services & 28 & 11.86 \\
Lack of finance & 26 & 11.02 \\
Knowledge gap/technology & 25 & 10.59 \\
Trustworthy employees & 19 & 8.05 \\
Leadership & 16 & 6.78 \\
Valuation of assets & 16 & 6.78 \\
Lack of supply of materials & 10 & 4.24 \\
Certification of goods & 9 & 3.81 \\
Lack of structure and political stability & 9 & 3.81 \\
Fear of KRA & 8 & 3.39 \\
Lack of systems & 3 & 1.27 \\
None & 1 & 0.42 \\
Total & 236 & 100.00 \\
\hline
\end{tabular}


Table 6. Regression of accounting systems on enterprise development.

\begin{tabular}{|c|c|c|c|}
\hline Goodness of fit & \multicolumn{2}{|c|}{ Test statistic } & $p$-value \\
\hline $\mathrm{R}$ & \multicolumn{2}{|c|}{0.720} & \\
\hline Adjusted R-squared & \multicolumn{2}{|c|}{0.503} & \\
\hline R-squared & \multicolumn{2}{|c|}{0.518} & \\
\hline \multirow[t]{2}{*}{ F-statistic $(1,223)$} & \multicolumn{2}{|c|}{56.011} & $0.000^{* *}$ \\
\hline & \multicolumn{3}{|c|}{ Linear Regression results } \\
\hline Dependent variable: enterprise development & Coefficients & t-statistic & $p$-value \\
\hline Constant & 3.685 & 18.788 & $0.000^{* *}$ \\
\hline Accounting systems & 0.900 & 9.047 & $0.001^{* *}$ \\
\hline
\end{tabular}

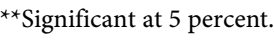

willing to delve to the researcher were a limitation. The government of Kenya through its revenue collecting body has been keen to loop in more people to pay taxes. The timing of the study coincided with a tax amnesty issued by the revenue authority. This was a deterrent to the entrepreneurs to answer all the questions in a concise and clear manner particularly those touching on business revenue.

Small enterprises contribute to poverty reduction, job creation, economic and human development, though they face a myriad of challenges in their day to day operations. The Makueni entrepreneurs' main accounting systems are for recording sales, purchases, expenses and maintaining records for costing their goods and services. The major challenges faced by the entrepreneurs in keeping records were lack of competent clerical staff, knowledge on record keeping and time to organize and keep the records. Entrepreneurs were noted to keep records in order to remember, observe progress and track profit. The entrepreneurs in Makueni County preferred the manual method of record keeping which is tedious, prone to error, difficult to track fraud and slow to generate financial reports for business decision making. The solution is to computerize the financial records by introduction of the management of information systems. The four factors found to be important in accounting systems were maintaining records for costing of goods and services, recording expenses and payments, recording sales and recording purchases. Accounting systems were statistically significant in influencing enterprise development. The stakeholders which include the national government, county government and other local organizations need to support small enterprises to improve on their accounting systems. This will result in increased revenue, job creation and accurate records to assist in decision and policy formulation.

The study considered the influence of accounting systems on enterprise development. Future research should investigate the influence of accounting methods, accounting policies and information technology influence on enterprise development in Kenya.

\section{References}

[1] Jenkins, B., Gilbert, R. and Baptista, P. (2014) Sustaining and Scaling the Impact of 
Enterprise Development Programmes: SABMiller's Approach to Strengthening Business Ecosystems. Havard Kennedy School and Business Fights Poverty, 1-44.

[2] Kirsten, C.L. and Fourie, J.R. (2012) The Accounting Professions' Role in Financial Management Skills Development of Small Businesses. Journal of Economic and Financial Sciences, 5, 459-480.

[3] Masutha, M. and Rogerson, C.M. (2014) Small Enterprise Development in South Africa: The Role of Business Incubators. Bulletin of Geography. Socio-Economic Series, No. 26, 141-155.

[4] Huq, A. and Moyeen, A. (2011) Gender Integration in Enterprise Development Programmes. Womens Studies International Forum, 34, 320-328. https://doi.org/10.1016/j.wsif.2011.04.007

[5] Republic of Kenya (RoK) (2013) Kenya Economic Report 2013.

[6] International Labour Organization (ILO) (2008) Factors Affecting Women Entrepreneurs in Micro and Small Enterprises in Kenya. ILO Publications, Geneva.

[7] Karanja, J.C.N., Mwangi, E. and Nyaanga, P. (2012) Adoption of Modern Management Accounting Techniques in Small and Medium (SMEs) in Developing Countries: A Case Study of SMEs in Kenya. St Paul's University, Kenya.

[8] Government of Kenya (GOK) (2013) Kenya Gazette Supplement Acts. Government of Kenya, Nairobi.

[9] Muteti, N.M., Namusonge, M. and Nzomo, D.N. (2018) Accounting Practices and Enterprise Development in Selected Small Enterprises in Makueni County. Unpublished Ph.D. Thesis, School of Business, Kenyatta University, Nairobi.

[10] Amoako, O.K., Marfo, E.O., Gyabaah, E.N. and Gyamfi, O. (2014) Accounting Records Keeping Practices of SMEs in Ghana: Evidence from Sunyani Municipality. British Journal of Economics, Finance and Management Sciences, 9, 120-132.

[11] Burns, P. (2005) Corporate Entrepreneurship: Building an Entrepreneurial Organisation. Simon and Schuster, New York.

[12] Ngwira, A.G. (1995) Small Enterprises or the Informal Sector? Small Enterprise Development. An International Journal, 6, 49-52.

[13] Agyei-mensah and Kwame, B. (2011) Financial Management Practices of Small Firms in Ghana: An Empirical Study. African Journal of Business Management, 5, 3781-3793.

[14] Kobe, K. (2012) Small Business GDP: Update 2002-2010. Economic Consulting Services, Berkeley, Washington DC.

[15] Özar, Š., Özertan, G., Irfanoğlu, Z.B., Ozertan, G. and Irfanoglu, Z.B. (2008) Micro and Small Enterprise Growth in Turkey: Under the Shadow of Financial Crisis. The Developing Economies, 46, 331-362. https://doi.org/10.1111/j.1746-1049.2008.00069.x

[16] Dodge, H. and Robbins, J.E. (1992) An Empirical Investigational of the Organization Life Cycle Model for Small Business Development and Survival. Journal of Small Business Management, 30, 27-37.

[17] Ooghe, H. (1998) Financial Management Practices in China: A Case Study Approach to Companies in the Shanghai Region. European Business Review, 98, 217-226. https://doi.org/10.1108/09555349810221844

[18] Ong'olo, D. and Awino, S. (2013) Small and Medium Enterprises and Devolved Government System: An Assessment of the Regulatory and Institutional Challenges Affecting the SMEs Development in Kenya. International Journal for Management Science and Technology, 3, 12-15. 
[19] Priya, D.G., Guha, S. and Shiva, S.K. (2013) Firm Growth and Its Determinants. Journal of Innovation and Entrepreneurship, 2, 15. https://doi.org/10.1186/2192-5372-2-15

[20] Kaplan, B. (2012) How Do I Assist in Enterprise Development through Action Research? Educational Research for Social Change, 1, 85-95.

[21] Padachi, K. (2012) Factors Affecting the Adoption of Formal Accounting Systems by SMEs. Business and Economics Journal, 1, 1-20.

[22] Fadhil, N.F.M. and Fadhil, N.F.M. (2011) Managing Company's Financial among Small and Medium Non-Manufacturing Companies. Far East Journal of Psychology and Business, 2, 17-36.

[23] Collier, P. and Nandan, R. (2010) Management Accounting Needs of SMEs and the Role of Professional Accountants: A Renewed Research Agenda. JAMAR, 8, 65-73.

[24] Mitchel, F., Smith, J. and Reaid, J. (2001) Information System Development in the Small Firm: The Use of Management Accounting (CIMA Research). CIMA Publishing.

[25] Okoli, B.E. (2011) Evaluation of the Accounting Systems Used by Small Scale Enterprises in Nigeria: The Case of Enugu-South East Nigeria. Asian Journal of Business Management, 3, 235-240. 